\title{
Sleep-enhancing Effects of Phytoncide Via Behavioral, Electrophysiological, and Molecular Modeling Approaches
}

\author{
Junsung Woo ${ }^{1}$ and C. Justin Lee ${ }^{2 *}$ \\ ${ }^{1}$ Center for Cell and Gene Therapy, Baylor College of Medicine, Houston, TX 77030, USA, \\ ${ }^{2}$ Center for Cognition and Sociality, Institute for Basic Science, Daejeon 34126, Korea
}

\begin{abstract}
Sleep is indispensable for living animals to live and maintain a normal life. Due to the growing number of people suffering from sleep disorders such as insomnia, there have been increasing interests in environmentally friendly therapeutic approaches for sleep disorders to avoid any side effects of pharmacological treatment using synthetic hypnotics. It has been widely accepted that the various beneficial effects of forest, such as relieving stress and anxiety and enhancing immune system function, are caused by plant-derived products, also known as phytoncide. Recently, it has been reported that the sleep-enhancing effects of phytoncide are derived from pine trees such as (-)- $\alpha$-pinene and 3-carene. These are the major constituents of pine tree that potentiate the inhibitory synaptic responses by acting as a positive modulator for $\mathrm{GABA}_{\mathrm{A}}-\mathrm{BZD}$ receptor. In this review, we discuss the effects of phytoncide on sleep and review the latest approaches of sleep-related behavioral assay, electrophysiological recording, and molecular modeling technique.
\end{abstract}

Key words: Sleep, GABA A $^{-B Z D}$ receptor, Phytoncide

\section{INTRODUCTION}

Sleep is defined as a naturally recurring state of mind and body, characterized by altered consciousness, relatively inhibited sensory activity, reduced muscle activity [1]. Sleep, also observed in nonhuman animals including mammals, birds, reptiles, amphibians, fish, even in insects [2-5], is indispensable for living animals to live and maintain normal life. There has been a growing number of people suffering from sleep disorders including dyssomnias such as insomnia, one of the most common sleep disorders and observed in one third of the general population in USA [6]. The market for sleep and sleep disorder treatment has been steadily increasing in proportion to the increasing number of people with sleep disorders each year. For the treatment of insomnia, there are

Submitted March 31,2020, Revised April 24, 2020,

Accepted April 27,2020

${ }^{*}$ To whom correspondence should be addressed.

TEL: 82-42-878-9155, FAX: 82-42-878-9151

e-mail:cjl@ibs.re.kr several therapeutic approaches such as behavioral therapy, psychotherapy and light therapy [7-9]. Among these approaches, the most common treatment is pharmacological treatment with hypnotics. There are various types of hypnotics including barbiturate, quinazolionones, benzodiazepines, and non-benzodiazepines [10-12]. The most common and widely used hypnotics are diazepam and zolpidem. Although diazepam belongs to benzodiazepines (BZDs) and zolpidem belongs to non-benzodiazepine also known as zdrug, they both bind to the $\mathrm{BZD}$ site of $\mathrm{GABA}_{\mathrm{A}}$ receptor. However, these drugs have various side effects, including cognitive impairment, tolerance, rebound insomnia upon discontinuation, abuse, and dependence liability [10]. These side effects might be caused by non-specific binding of hypnotics to other ion channels and transporters rather than $\mathrm{GABA}_{\mathrm{A}}$ receptor [13-16]. To avoid these side effects of pharmacological treatment, there have been increasing interests in environmentally friendly therapeutic approaches for sleep disorders.

Although there are various causes for sleep disorders including medical conditions such as respiratory disorders, diabetes, pain, anxiety, and depression, the most fundamental cause of sleep 
Table 1. Representative studies showing various biological effects of phytoncides including a-pinene and 3-carene

\begin{tabular}{|c|c|c|}
\hline Literature & Approaches & Main finding \\
\hline Park et al. [19] & $\begin{array}{l}\text { Physiological parameter measure (Cerebral activity, } \\
\text { Salivary cortisol) }\end{array}$ & Forest bathing reduced the cerebral activity and stress hormone \\
\hline Gomes-Carneiro et al. [38] & Salmonella/microsome assay & $\begin{array}{l}\text { Inhalation of } \alpha \text {-pinene showed anxiolytic effect } \\
\text { Detection of accumulated } \alpha \text {-pinene in bran and liver }\end{array}$ \\
\hline Satou et al. [32] & $\begin{array}{l}\text { Anxiety behavior (elevated plus maze) measure } \\
\text { a-pinene detecting in organs by gas chromatography }\end{array}$ & $\begin{array}{l}\text { Inhalation of } \alpha \text {-pinene showed anxiolytic effect } \\
\text { Detection of accumulated } \alpha \text {-pinene in bran and liver }\end{array}$ \\
\hline Yamaoka et al. [39] & Sleep behavior measure & Inhalation of $a$-pinene increased the REMS \\
\hline Yang et al. [33] & $\begin{array}{l}\text { Sleep behavior measure } \\
\text { Electrophysiology } \\
\text { Molecular medeling }\end{array}$ & $\begin{array}{l}\text { Oral administration of } \alpha \text {-pinene increased the NREMS, pro- } \\
\text { longed the GABA response } \\
\text { The binding site of } \alpha \text {-pinene in } \mathrm{GABA}_{\mathrm{A}} \mathrm{BZD} \text { receptor was pre- } \\
\text { dicted }\end{array}$ \\
\hline Ocete et al. [40] & Anti-inflammatory assay & $\begin{array}{l}\text { Oral / intraperitoneally administration 3-carene showed the } \\
\text { anti-inflammatory effect }\end{array}$ \\
\hline Woo et al. [34] & $\begin{array}{l}\text { Electrophysiology } \\
\text { Molecular medeling }\end{array}$ & $\begin{array}{l}\text { Oral administration of 3-carene prolonged the GABA response } \\
\text { The binding site of } \alpha \text {-pinene in } \mathrm{GABA}_{\mathrm{A}} \mathrm{BZD} \text { receptor was pre- } \\
\text { dicted }\end{array}$ \\
\hline
\end{tabular}

disorders is stress $[17,18]$. There has been growing interest in forest bathing, defined as making contact with and taking in the atmosphere of the forest, as an environmentally friendly therapeutic approach for improving an individual's mental and physical relaxation and relieving stress [19-21]. Park et al. [19] reported the physiological effect of forest bathing by demonstrating the reduction of the stress hormone, blood pressure and pulse rate through forest walking. It has been reported that the various beneficial effects of the forest bathing are due to plant-derived substance or phytoncide, defined as natural volatile compounds derived from trees and plants [22-24]. The ancient Chinese and Korean medicinal literatures have described the therapeutic effects of pine tree seeds in digestive function, stress, and sleep and usage of pine tree seeds in symptoms or diseases related to stress and sleep $[25,26]$.

Phytoncides, firstly coined in 1928 by Boris P. Tokin, a Russian biochemist, are antimicrobial allelochemic volatile organic compounds emitted by plants to defend against decay or attack by herbivores. The various beneficial effects of phytoncide such as antifungal, anti-inflammatory, anti-microbial, analgesic, and anti-stress have been reported [27-31]. In addition, recent studies reported a sleep enhancing effect of phytoncide from pine tree [32-34]. Although many plants including onion, garlic, cedar, and pine can emit phytoncides, we focus on the role of phytoncides from the pine tree, the most abundant tree in South Korean forest, on sleep.

\section{PHYTONCIDES DERIVED FROM PINE TREE}

The pine tree is classified as any conifer in the genus Pinus of the family Pinaceae. Pinus is the sole genus in the subfamily Pinoideae [35-37]. Pine includes conifers such as cedars, spruces, firs and pines. Of all the conifers, the pines have one of the largest distributions in the world, although they are found almost entirely in the northern hemisphere. They are found throughout much of the North America, China, South-East Asia including South Korea, Russia and Europe. Pines have been used in everyday life and throughout the world for their unique aroma and various therapeutic potentials. These are derived from pine essential oils, also known as phytoncide [22-24]. Pine essential oils are mainly composed of monoterpene such as $\alpha$ - and $\beta$-pinene, 3 -carene, limonene, and terpinene. These compounds have versatile properties such as anti-fungal, anti-inflammatory, anti-microbial, analgesic, and anti-stress (Table 1) [19,27-34,38-40].

a-Pinene [2,6,6,-trimethylbicyclo(3.1.1)-2-hept-2-ene)] is the most abundant terpene of pine essential oils and it has a hydrocarbon group of bicylic terpenes with a distinctive turpentine odor (Fig. 1) [41]. It has been widely used as a food flavoring ingredient and component of perfumes [42]. Besides its various biological properties including anti-microbial, hypertensive, anti-nociceptive, and anti-inflammatory $[29,38,43,44]$, it also has an anxiolytic effect and sleep enhancing effect by inhalation and oral administration [32, 33, 39]. 3-Carene (3,7,7-Trimethylbicyclo[4.1.0] hept-3-ene), the second abundant terpene of pine essential oils, is a bicyclic monoterpene consisting of fused cyclohexene and cyclopropane rings and has a sweet and pungent odor (Fig. 1) [45]. It has been utilized as a raw material in perfumes, cosmetics, flavors and terpene resins, having various therapeutic properties like other pine essential oils $[40,46]$. Recently, a sleep enhancing effect of 3-carene by oral administration just like $\alpha$-pinene has been reported $[33,34]$. Although pine essential oils have various biological and therapeutic effects, we focus on the sleep enhancing effects by the most abundant terpenes: $\alpha$-pinene and 3 -carene. 
<smiles>CN1C(=O)CN=C(c2ccccc2)c2cc(Cl)ccc21</smiles>

Diazepam

C16H13CIN2O (MW: 284.74)<smiles>CC1=CCC2CC1C(C)(C)C21CCCCC1</smiles>

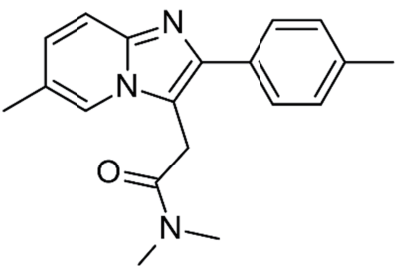

Zolpidem

$\mathrm{C}_{23} \mathrm{H}_{27} \mathrm{O}_{7}$ (MW: 457.48)

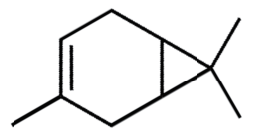

(+)-3-Carene

$\mathrm{C}_{10} \mathrm{H}_{16}(\mathrm{MW}: 136.24)$<smiles>CCOC(=O)c1ncn2c1CN(C)C(=O)c1cc(F)ccc1-2</smiles>

Flumazenil

$\mathrm{C}_{15} \mathrm{H}_{14} \mathrm{FN}_{3} \mathrm{O}_{3}(\mathrm{MW}: 303.29)$

Fig. 1. Chemical structures and molecular weight (MW) of Diazepam, Zolpidem, Flumazenil, a-pinene and 3-carene.

\section{SLEEP BEHAVIORAL STUDY OF PHYTONCIDE WITH EEG AND EMG}

Sleep is divided into two broad stages: non-rapid eye movement sleep (non-REMS or NREMS) and rapid eye movement sleep (REMS). NREMS is further divided into 4 sub-stages of increasing depth leading to REMS. REMS represents a smaller portion of total sleep time, and is associated with desynchronized and fast brain waves, eye movements, loss of muscle tone, and suspension of homeostasis [47]. Sleep stages can be monitored and measured by the well-known techniques; electroencephalogram (EEG) and electromyogram (EMG). EEG is an electrophysiological monitoring method to record electrical activity of the brain, measuring voltage fluctuations resulting from ionic current within the neurons of the brain [48]. EEG can be utilized in various medical applications such as diagnosis of epilepsy, sleep disorders, depth of anesthesia, and brain death. In an EEG recording, the brain waves are a commonly used criteria for distinguishing sleep stages. Brain waves can be classified as alpha, beta, delta, and theta based on their own frequency and amplitude. EMG is an eletrodiagnostic medical technique for recording the electrical activity produced by skeletal muscles [49]. EMG has various clinical and biomedical applications. It is used as a diagnostic tool for identifying neuromuscular diseases, motor disorders, and sleep stages.

Yamaoka et al. [39] firstly reported the role of phytoncide from pine tree on sleep. They found that inhalation of $(+) \alpha$-pinene in rats increased the duration of paradoxical sleep, also known as REMS through EEG and EMG recordings [39]. In another study, an oral administration of (-) $a$-pinene showed a sedative effect at a low dose $(<25 \mathrm{mg} / \mathrm{kg})$ and increased NREMS at high dose
(100 mg/kg, Fig. 2a) in mice [33]. The discrepancy of the effect of a-pinene on REMS and NREMS might be due to different administration methods, concentration, enantiomer type, or species. It has been previously established that sleep quantity, as measured by increased duration of NREMS, is enhanced by well-known hypnotics such as diazepam and zolpidem $[50,51]$. However, a major pitfall of these hypnotics is that they reduce the delta activity, a high amplitude brain wave with a frequency of oscillation between 0.5 and $4 \mathrm{~Hz}$ in EEG recording [52-54]. It has been widely accepted that delta activity is observed in the deep stage 3 of NREMS and is a critical index for the depth or intensity of NREMS $[51,52]$. When we think about a good sleep or efficient sleep, we need to consider not only sleep quantity but also sleep quality. Although it is not trivial to define sleep quality in rodents, the delta activity would be a good indicator for the intensity of NREMS or sleep quality $[51,52]$. Unlike conventional hypnotics such as zolpidem, a-pinene is shown to increase the duration of NREMS without affecting the delta activity (Fig. 2b) [33]. This is in great contrast to zolpidem, which causes increased duration of NREMS accompanied by a significantly reduced delta activity (Fig. 2b) [33]. These results suggest that $\alpha$-pinene has a sleep-enhancing effect with an increase of sleep quantity, but no change in sleep quality. The sleep enhancing effect of $\alpha$-pinene was fully blocked by flumazenil, an antagonist of the $\mathrm{GABA}_{\mathrm{A}}$-BZD receptor (Fig. 2a) $[33,55,56]$, suggesting that $\alpha$-pinene works as a modulator of $\mathrm{GABA}_{\mathrm{A}}-\mathrm{BZD}$ receptor, just like diazepam and zolpidem. Based on the pharmacological evidence using flumazenil in EEG recording, the next obvious question is what is the molecular mechanism of a-pinene in action. This question can be addressed by the next scientific approach: electrophysiological recording from brain slices. 


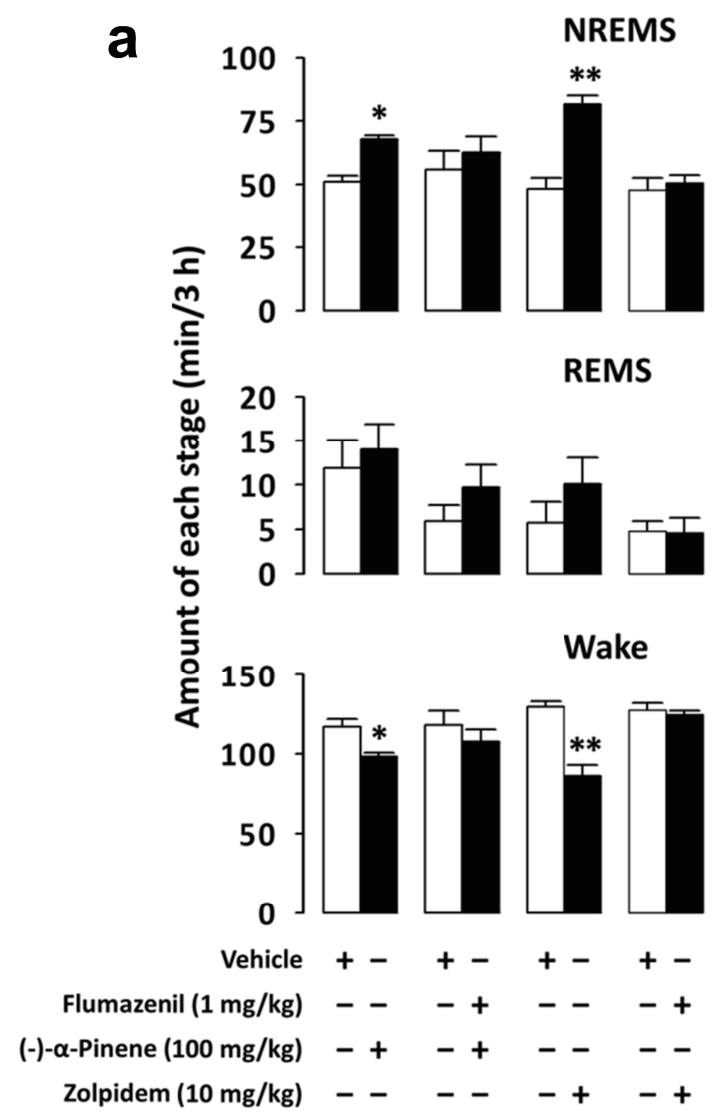

\section{MOLECULAR MECHANISM OF PHYTONCIDE THROUGH ELECTROPHYSIOLOGICAL APPROACH}

It has been reported that hypnotics such as diazepam and zolpidem enhance GABAergic inhibitory signaling by prolonging the decay time constant of $\mathrm{GABA}_{\mathrm{A}}$ receptors in various brain region including thalamus, hippocampus, and neocortex [33, 34, 57 59]. Recent studies also reported that phytoncides from pine tree such as a-pinene and 3-carene show the same prolonging effect on IPSCs (inhibitory postsynaptic currents, Fig. 3) in CA1 hippocampus $[33,34]$ just like diazepam and zolpidem. Interestingly, these two components of pine tree did not affect the amplitude and frequency of IPSCs, an indicator for changes in presynaptic and postsynaptic component such as the amount of presynaptic release of transmitters and the number of postsynaptic receptors in inhibitory signaling [60-63]. The prolonging effect in inhibitory signaling by a-pinene and 3-carene was fully blocked by flumazenil, suggesting that these two phytoncide components modulate the $\mathrm{GABA}_{\mathrm{A}} \mathrm{BZD}$ receptor with having the same molecular mechanism with diazepam and zolpidem.

Besides these monoterpenes from pine tree, other natural compounds from various plants such as borneol, verbenol, pinocar-
.... Vehicle

- (-)- $\alpha$-Pinene $(100 \mathrm{mg} / \mathrm{kg})$

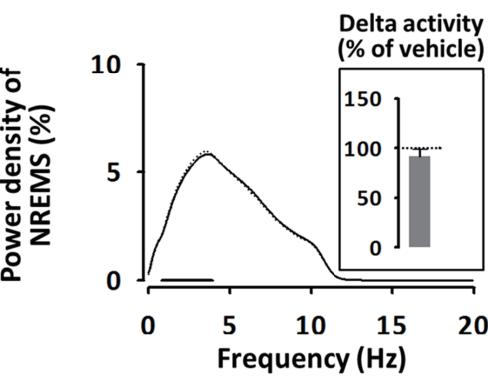

.... Vehicle

— Zolpidem (10 mg/kg)

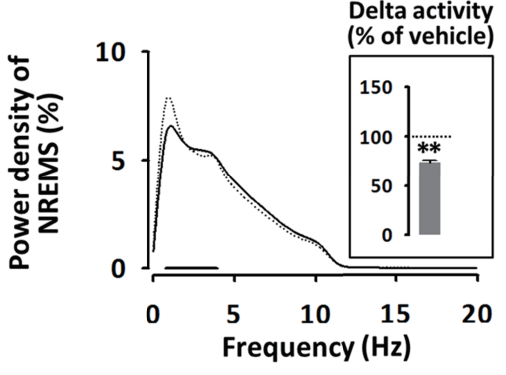

Fig. 2. (a) Effect of $\alpha$-pinene and zolpidem on sleep stage: NREMS, REMS and wake. $\alpha$-pinene and zolpidem increased the amount of NREMS and wave stages. This enhancement was fully inhibited by flumazenil. (b) Effect of a-pinene and zolpidem on delta activity. a-pinene did not change the delta activity. Yang et al., 2014, Mol. Pharm.

veol, and isoliquiritigenin show the similar effect on GABAergic inhibitory signaling as a modulator for $\mathrm{GABA}_{\mathrm{A}} \mathrm{BZD}$ receptor with sleep-enhancing effects $[50,59,64-66]$. Based on these lines of evidence, we can make a generalization that if a certain drug or compound prolongs the decay time constant of IPSCs, we can predict that it could have a sleep-enhancing effect as a positive modulator of $\mathrm{GABA}_{\mathrm{A}} \mathrm{BZD}$ receptor. This electrophysiological experiment could be a simple screening method for finding a potential hypnotic. In addition to the change in sIPSCs decay time, it has been reported the hyperpolarization of membrane potential from cortical neurons through the influx of chloride ion by hypnotics such as diazepam and zolpidem [67-69]. Future experiments are needed to confirm the hyperpolarization of membrane potential in neurons by phytoncide including $\alpha$-pinene and 3-carene. It has been reported the non-specific binding of hypnotics to other ion channels and transporters rather than $\mathrm{GABA}_{\mathrm{A}}$ receptor [13-16]. Future experiments are required to test the non-specific binding of phytoncide relating to side effects such as cognitive defect. 
a

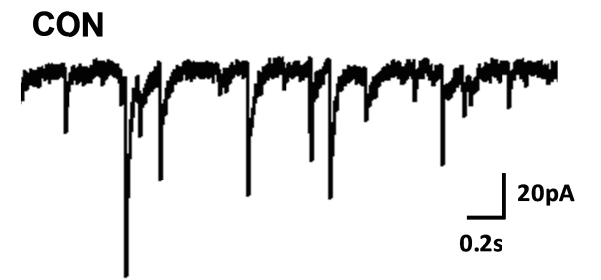

(-)- $\alpha-$ Pinene $(10 \mu M)$

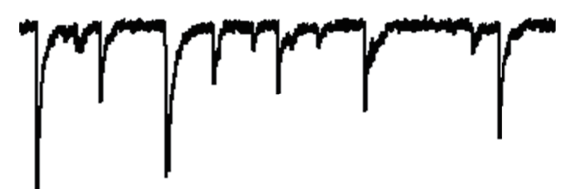

b

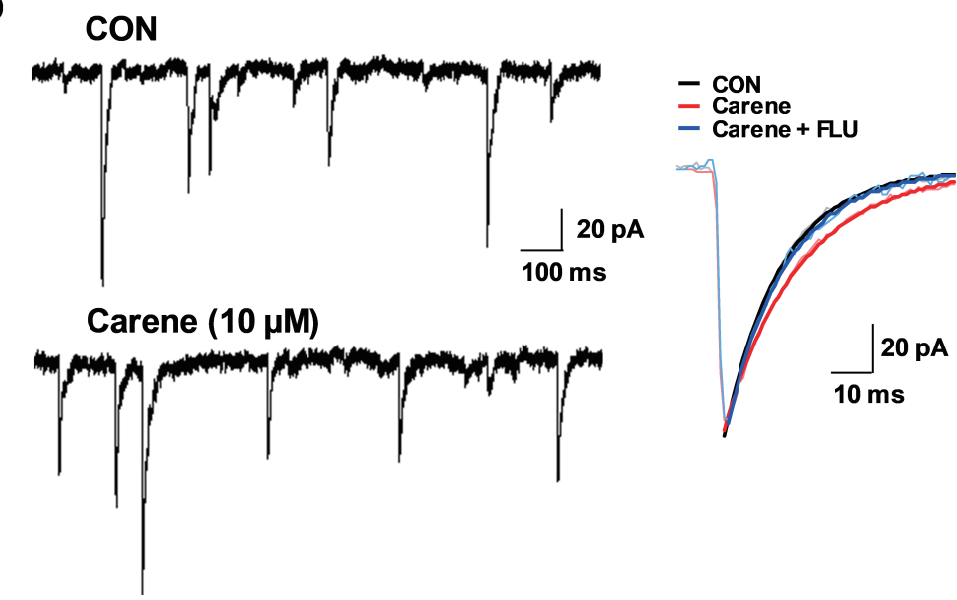

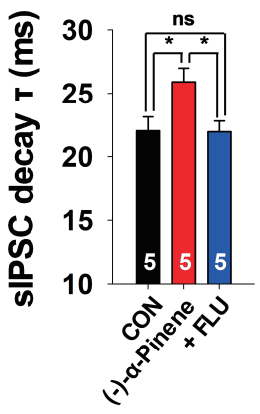
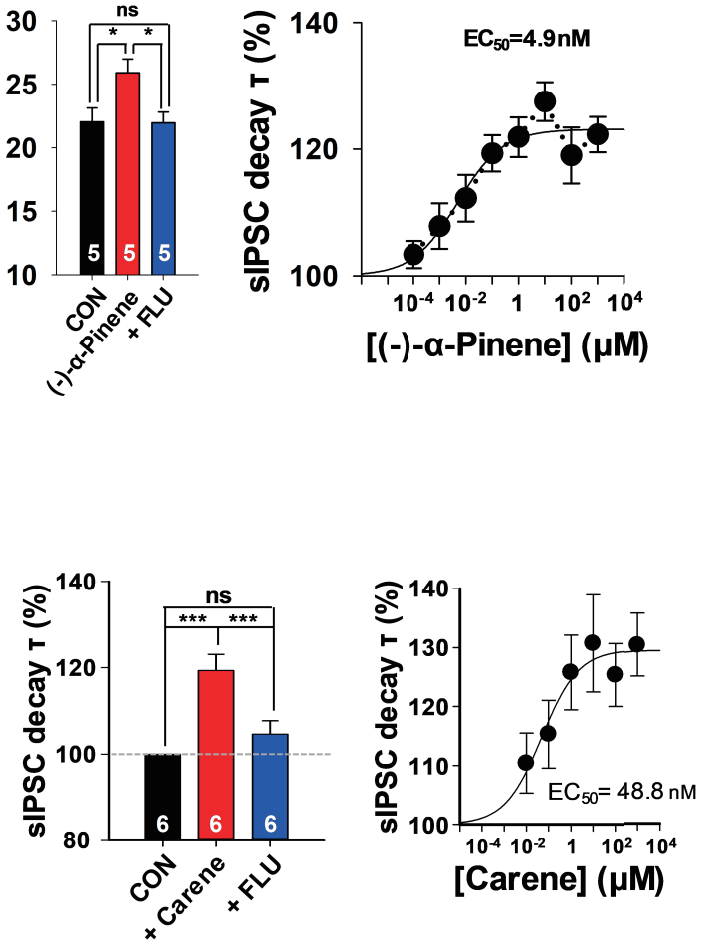

Fig. 3. Effect of a-pinene (a) and 3-carene (b) on GABAergic inhibitory signaling. a-Pinene and 3-carene prolonged the decay time constant of GABA receptors. This enhancement was fully blocked by flumazenil. (a) from Yang et al., 2014, Mol. Pharm., (b) from Woo et al., 2019, Exp. Neurobiol.

\section{STRUCTURAL BIOLOGICAL APPROACH THROUGH MOLECU- LAR DOCKING MODEL}

The sleep-enhancing effect of $\alpha$-pinene and 3-carene has been demonstrated by pharmacological method using well-known modulator and antagonist of $\mathrm{GABA}_{\mathrm{A}} \mathrm{BZD}$ receptor, sleep behavioral approach using EEG, and electrophysiological approach using patch-clamp technique $[33,34]$. However, additional validation of the molecular mechanism with more advanced in-depth analysis is needed to demonstrate how and where the chemical constituent of each phytoncide bind to $\mathrm{GABA}_{\mathrm{A}} \mathrm{BZD}$ receptor. This can be achieved by the latest tools available from the structural biology, the study of the molecular structure and dynamics of biological molecules, and how alterations in their structures affect their function [70].

It has been shown that $\alpha$-pinene, zolpidem, and flumazenil bind to BZD binding site between $\alpha 1$ and $\Upsilon 2$-subunits in extracellular domain of $\mathrm{GABA}_{\mathrm{A}}$ receptor through the molecular modeling, encompassing theoretical and computational methods to model or mimic the behavior of the molecules [33]. Contrary to zolpidem and flumazenil having $\pi-\pi$ interaction with $\alpha 1$ and $\Upsilon 2$-subunits in extracellular domain of $\mathrm{GABA}_{\mathrm{A}}$ receptor, it was predicted that a-pinene makes strong hydrophobic interactions with aromatic residues of $\alpha 1$ and $\Upsilon 2$-subunits, suggesting the lower binding energy and affinity of $\alpha$-pinene compared to zolpidem and flumazenil (Fig. 4a and 4b). Through the same approach, it was predicted that 3 -carene also binds to BZD binding site between $\alpha 1$ and $\Upsilon 2$ subunits in extracellular domain of $\mathrm{GABA}_{\mathrm{A}}$ receptor. 3-Carene has three different bonds including van der Waals, $\pi-\pi$, and $\pi-\sigma$ interactions with $\alpha 1$ and $\Upsilon 2$-subunits (Fig. 4d and 4e) [34]. Based on Glide score (GScore), an empirical scoring function that approximates the ligand binding free energy, 3-carene (GScore: -5.39 kcal/ $\mathrm{mol}$ ) has lower binding energy and affinity than a-pinene (GScore: $-6.57 \mathrm{kcal} / \mathrm{mol}$ ), zolpidem (GScore: $-9.22 \mathrm{kcal} / \mathrm{mol}$ ), and fluma- 
a

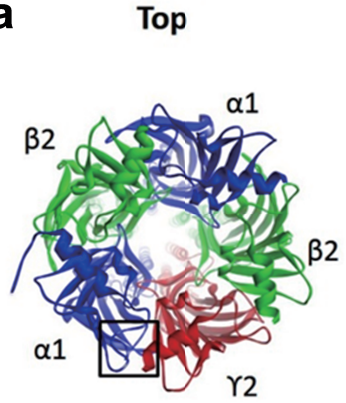

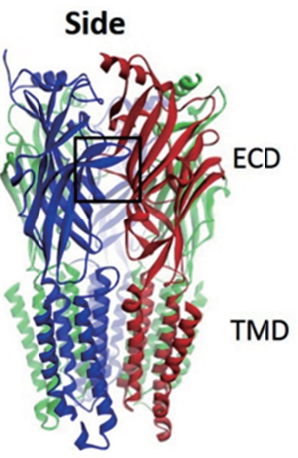

b

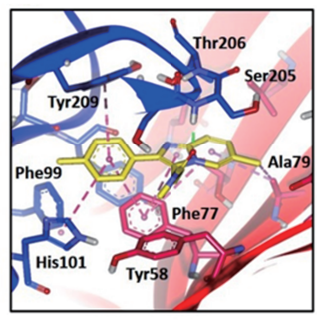

Zopidem

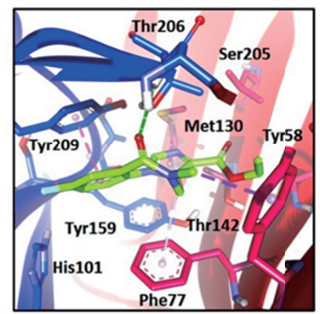

Flumazenil

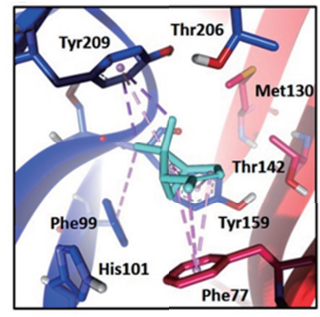

a-Pinene
C

d

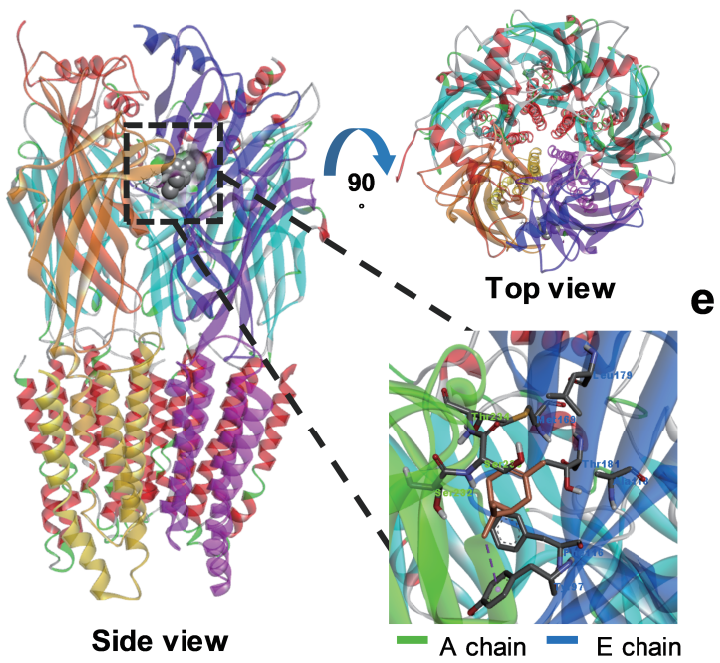

Fig. 4. Docking model of $\alpha$-pinene and 3 -carene in BZD binding site of $\mathrm{GABA}_{\mathrm{A}}$ receptor. Top and side views of GABA $\mathrm{A}_{\mathrm{A}}$ receptor homology model (a),

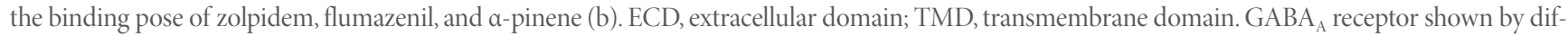
ferent chain color (c). Docking model of 3-carene interacting residues on $\mathrm{GABA}_{\mathrm{A}}$ receptor (d). Various interactions between 3-carene and surrounding residues of $\mathrm{GABA}_{\mathrm{A}}$ receptor (e). (a,b) from Yang et al., 2014, Mol. Pharm., (c-e) from Woo et al., 2019, Exp. Neurobiol.

zenil (GScore: $-8.78 \mathrm{kcal} / \mathrm{mol}$ ) [33, 34]. Through this molecular modeling, we can predict that $\alpha$-pinene and 3 -carene modulate the biologic function of $\mathrm{GABA}_{\mathrm{A}}$ receptor by directly binding at the BZD binding site.

It has been reported that $\alpha 1 / \alpha 3$ subunits of the $\mathrm{GABA}_{\mathrm{A}}$ receptor are predominant in the corticothalamic network, which is responsible for the generation of delta activity [71-73]. a-Pinene and 3-carene have lower binding energy and affinity to al subunit of $\mathrm{GABA}_{\mathrm{A}}$ receptor through a hydrophobic interaction $[33,34]$. This biomolecular property might be the reason that a-pinene did not affect delta activity indicating sleep quality. Future experiments are needed to identify the relationship between the binding property of hypnotics and the degree of side effects, including a decrease in sleep quality.

\section{CONCLUDING REMARKS}

We have discussed the sleep-enhancing effect of phytoncides from pine trees through behavioral, pharmacological, electrophysiological, and structural approaches (Fig. 5). Through these approaches, it has been established that major phytoncides including a-pinene and 3-carene enhance the quantity of NREMS without affecting the sleep quality by prolonging GABAergic inhibitory signaling as a positive modulator of $\mathrm{GABA}_{\mathrm{A}} \mathrm{BZD}$ receptor. Although other natural compounds from various plants can have a similar effect in sleep like phytoncide, we can obtain phytoncide's beneficial effects including anxiolytic, anti-stress, and sleep enhancing effects from our daily life such as strolling in the woods or forest-bathing. It has been reported that conventional hypnotics such as diazepam and zolpidem have various side effects including cognitive impairment, tolerance, rebound insomnia upon discontinuation, abuse, and dependence liability. These side-effects are 

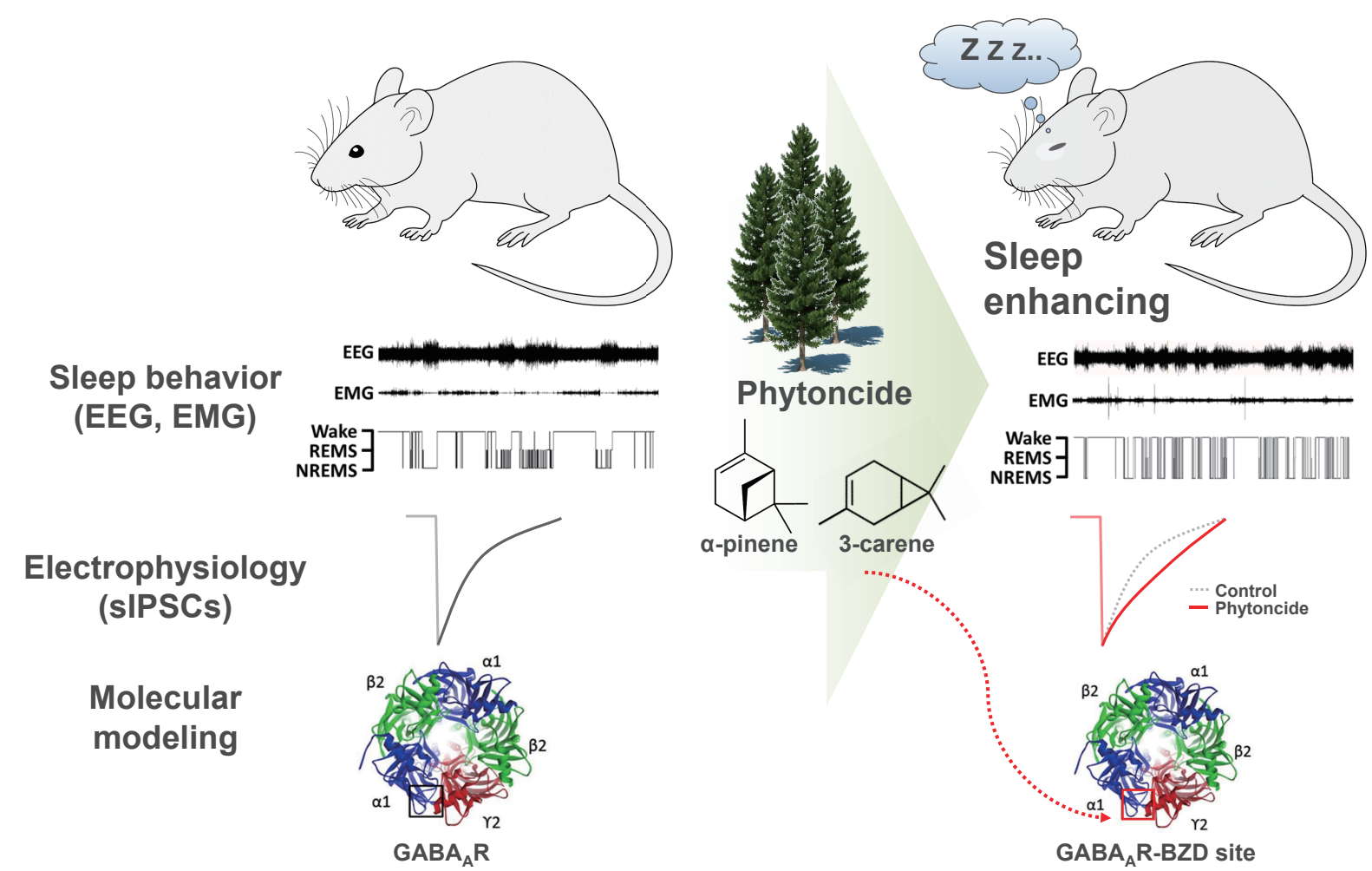

Fig. 5. Sleep enhancing effect of phytoncide from pine tree through sleep behavioral, pharmacological, electrophysiological, and structure biological approaches.

becoming increasingly serious as more people experience sleep disorders. Studies on the sleep-enhancing effects of $\alpha$-pinene and 3 -carene raise the possibility that these phytoncides might have less side-effects compared to the conventional hypnotics. Future work is needed to directly compare between phytoncides and existing hypnotics in terms of the side-effects. Furthermore, recent studies verify the effects of forest bathing scientifically and suggest screening tools for identifying prospective hypnotics from natural compounds.

\section{REFERENCES}

1. Ferri R, Manconi M, Plazzi G, Bruni O, Vandi S, Montagna P, Ferini-Strambi L, Zucconi M (2008) A quantitative statistical analysis of the submentalis muscle EMG amplitude during sleep in normal controls and patients with REM sleep behavior disorder. J Sleep Res 17:89-100.

2. Allison T, Cicchetti DV (1976) Sleep in mammals: ecological and constitutional correlates. Science 194:732-734.

3. Ramón F, Hernández-Falcón J, Nguyen B, Bullock TH (2004) Slow wave sleep in crayfish. Proc Natl Acad Sci U S A 101:11857-11861.
4. Flanigan WF Jr (1973) Sleep and wakefulness in iguanid lizards, Ctenosaura pectinata and Iguana iguana. Brain Behav Evol 8:401-436.

5. Rattenborg NC (2006) Evolution of slow-wave sleep and palliopallial connectivity in mammals and birds: a hypothesis. Brain Res Bull 69:20-29.

6. Statistic Stats (2017) Insomnia statistics sleep facts [Internet]. Statistic Stats, Phoenix. Available from: https://www.statisticstats.com/health/insomnia-statistics-sleep-facts/.

7. Sloane PD, Figueiro M, Cohen L (2008) Light as therapy for sleep disorders and depression in older adults. Clin Geriatr 16:25-31.

8. Talbot LS, Maguen S, Metzler TJ, Schmitz M, McCaslin SE, Richards A, Perlis ML, Posner DA, Weiss B, Ruoff L, Varbel J, Neylan TC (2014) Cognitive behavioral therapy for insomnia in posttraumatic stress disorder: a randomized controlled trial. Sleep 37:327-341.

9. Bathgate CJ, Edinger JD, Krystal AD (2017) Insomnia patients with objective short sleep duration have a blunted response to cognitive behavioral therapy for insomnia. Sleep. doi: 10.1093/sleep/zsw012.

10. Atkin T, Comai S, Gobbi G (2018) Drugs for insomnia be- 
yond benzodiazepines: pharmacology, clinical applications, and discovery. Pharmacol Rev 70:197-245.

11. Drake CL, Roehrs T, Roth T (2003) Insomnia causes, consequences, and therapeutics: an overview. Depress Anxiety 18:163-176.

12. Shorter E (2005) Benzodiazepines. In: A historical dictionary of psychiatry (Shorter E, ed), pp 37-42. Oxford University Press, Oxford.

13. Taft WC, DeLorenzo RJ (1984) Micromolar-affinity benzodiazepine receptors regulate voltage-sensitive calcium channels in nerve terminal preparations. Proc Natl Acad Sci U S A 81:3118-3122.

14. Jacob MK, White RE (2000) Diazepam, gamma-aminobutyric acid, and progesterone open $\mathrm{K}(+)$ channels in myocytes from coronary arteries. Eur J Pharmacol 403:209-219.

15. Jehle J, Ficker E, Wan X, Deschenes I, Kisselbach J, Wiedmann F, Staudacher I, Schmidt C, Schweizer PA, Becker R, Katus HA, Thomas D (2013) Mechanisms of zolpidem-induced long QT syndrome: acute inhibition of recombinant hERG $\mathrm{K}(+)$ channels and action potential prolongation in human cardiomyocytes derived from induced pluripotent stem cells. Br J Pharmacol 168:1215-1229.

16. Palmada M, Böhmer C, Centelles JJ, Kinne RK (1999) Effect of benzodiazepines on the epithelial and neuronal high-affinity glutamate transporter EAAC1. J Neurochem 73:23892396.

17. Kalmbach DA, Anderson JR, Drake CL (2018) The impact of stress on sleep: pathogenic sleep reactivity as a vulnerability to insomnia and circadian disorders. J Sleep Res 27:e12710.

18. Levenson JC, Kay DB, Buysse DJ (2015) The pathophysiology of insomnia. Chest 147:1179-1192.

19. Park BJ, Tsunetsugu Y, Kasetani T, Hirano H, Kagawa T, Sato M, Miyazaki Y (2007) Physiological effects of Shinrin-yoku (taking in the atmosphere of the forest)--using salivary cortisol and cerebral activity as indicators. J Physiol Anthropol 26:123-128.

20. Ulrich RS (1983) Aesthetic and affective response to natural environment. In: Behavior and the natural environment (Altman I, Wohlwill JF, eds), pp 85-125. Springer, Boston.

21. The Editors of Sunset (2010) Western garden book of edibles: the complete $\mathrm{A}$ to $\mathrm{Z}$ guide to growing your own vegetables, herbs, and fruits. p 304. Sunset Publishing, Menlo Park, CA.

22. Hmamouchi M, Hamamouchi J, Zouhdi M, Bessiere JM (2001) Chemical and antimicrobial properties of essential oils of five Moroccan pinaceae. J Essent Oil Res 13:298-302.

23. Matsubara E, Kawai S (2018) Gender differences in the psychophysiological effects induced by VOCs emitted from
Japanese cedar (Cryptomeria japonica). Environ Health Prev Med 23:10.

24. Independent Administrative Agency Forestry Research Institute (2011) Comparison of therapy effects in different natural environments and research on familiar forest therapy effect. In: Forestry Research Institute Grant Project Research Outcome Collection, vol. 46; 2011.p. 1-42. (in Japanese).

25. Heo J (1613) Donguibogam. Namsandang, Seoul.

26. Lee S (1596) Compendium of materia medica. Renmin weisheng, Beijing.

27. Süntar I, Tumen I, Ustün O, Keleş H, Akkol EK (2012) Appraisal on the wound healing and anti-inflammatory activities of the essential oils obtained from the cones and needles of Pinus species by in vivo and in vitro experimental models. J Ethnopharmacol 139:533-540.

28. Xie Q, Liu Z, Li Z (2015) Chemical composition and antioxidant activity of essential oil of six pinus taxa native to China. Molecules 20:9380-9392.

29. Astani A, Schnitzler P (2014) Antiviral activity of monoterpenes beta-pinene and limonene against herpes simplex virus in vitro. Iran J Microbiol 6:149-155.

30. Li Q, Nakadai A, Matsushima H, Miyazaki Y, Krensky AM, Kawada T, Morimoto K (2006) Phytoncides (wood essential oils) induce human natural killer cell activity. Immunopharmacol Immunotoxicol 28:319-333.

31. Abe T, Hisama M, Tanimoto S, Shibayama H, Mihara Y, Nomura M (2008) Antioxidant effects and antimicrobial activites of phytoncide. Biocontrol Sci 13:23-27.

32. Satou T, Kasuya H, Maeda K, Koike K (2014) Daily inhalation of $\alpha$-pinene in mice: effects on behavior and organ accumulation. Phytother Res 28:1284-1287.

33. Yang H, Woo J, Pae AN, Um MY, Cho NC, Park KD, Yoon M, Kim J, Lee CJ, Cho S (2016) a-Pinene, a major constituent of pine tree oils, enhances non-rapid eye movement sleep in mice through GABAA-benzodiazepine receptors. Mol Pharmacol 90:530-539.

34. Woo J, Yang H, Yoon M, Gadhe CG, Pae AN, Cho S, Lee CJ (2019) 3-Carene, a phytoncide from pine tree has a sleepenhancing effect by targeting the GABAA-benzodiazepine receptors. Exp Neurobiol 28:593-601.

35. Doty WL, Johnson PC (1954) Sunset western garden book. 1st ed. p 384. Lane Pub. Co., Menlo Park, CA.

36. Ioannou E, Koutsaviti A, Tzakou O, Roussis V (2014) The genus pinus: a comparative study on the needle essential oil composition of 46 pine species. Phytochem Rev 13:741-768.

37. Judzentiene A, Kupcinskiene E (2008) Chemical composition on essential oils from needles of Pinus sylvestris L. grown in 
Northern Lithuania. J Essent Oil Res 20:26-29.

38. Gomes-Carneiro MR, Viana ME, Felzenszwalb I, Paumgartten FJ (2005) Evaluation of beta-myrcene, alpha-terpinene and (+)- and (-)-alpha-pinene in the Salmonella/microsome assay. Food Chem Toxicol 43:247-252.

39. Yamaoka S, Tomita T, Imaizumi Y, Watanabe K, Hatanaka A (2005) Effects of plant-derived odors on sleep-wakefulness and circadian rhythmicity in rats. Chem Senses 30 Suppl 1:i264-i265.

40. Ocete MA, Risco S, Zarzuelo A, Jimenez J (1989) Pharmacological activity of the essential oil of Bupleurum gibraltaricum: anti-inflammatory activity and effects on isolated rat uteri. J Ethnopharmacol 25:305-313.

41. de Groot P, Nott R, MacDonald L (2002) Influence of enantiomers of $\alpha$-pinene on the response of the red pine cone beetle, Conophthorus resinosae to its pheromone pityol. Entomol Exp Appl 105:169-174.

42. U.S. Food and Drug Administration (2015) CFR - Code of Federal Regulations Title 21 [Internet]. U.S. Food and Drug Administration, Silver Spring. Available from: https://www. accessdata.fda.gov/scripts/cdrh/cfdocs/cfcfr/cfrsearch.cfm.

43. Kamal EH, Al-Ajmi MF, Al-Bekairi AM (2003) Some cardiovascular effects of the dethymoquinonated Nigella sativa volatile oil and its major components $\alpha$-pinene and $p$-cymene in rats. Saudi Pharm J 11:104-110.

44. Him A, Ozbek H, Turel I, Oner AC (2008) Antinociceptive activity of alpha-pinene and fenchone. Pharmacologyonline 3:363-369.

45. Chipman-Shlaes N (2007) The Merck index: an encyclopedia of chemicals, drugs, and biologicals. Choice 44:1724-1726.

46. Gil ML, Jimenez J, Ocete MA, Zarzuelo A, Cabo MM (1989) Comparative study of different essential oils of Bupleurum gibraltaricum Lamarck. Pharmazie 44:284-287.

47. Dement W, Kleitman N (1957) The relation of eye movements during sleep to dream activity: an objective method for the study of dreaming. J Exp Psychol 53:339-346.

48. Niedermeyer E, Lopes da Silva FH (2004) Electroencephalography: basic principles, clinical applications, and related fields. 5th ed. Lippincott Williams \& Wilkins, Philadelphia.

49. Kamen G, Gabriel DA (2010) Essentials of electromyography. Human Kinetics, Champaign.

50. Cho S, Kim S, Jin Z, Yang H, Han D, Baek NI, Jo J, Cho CW, Park JH, Shimizu M, Jin YH (2011) Isoliquiritigenin, a chalcone compound, is a positive allosteric modulator of GABAA receptors and shows hypnotic effects. Biochem Biophys Res Commun 413:637-642.

51. Chen CR, Zhou XZ, Luo YJ, Huang ZL, Urade Y, Qu WM
(2012) Magnolol, a major bioactive constituent of the bark of Magnolia officinalis, induces sleep via the benzodiazepine site of GABA(A) receptor in mice. Neuropharmacology 63:11911199.

52. Tobler I, Kopp C, Deboer T, Rudolph U (2001) Diazepaminduced changes in sleep: role of the alpha $1 \mathrm{GABA}(\mathrm{A})$ receptor subtype. Proc Natl Acad Sci U S A 98:6464-6469.

53. van Lier H, Drinkenburg WH, van Eeten YJ, Coenen AM (2004) Effects of diazepam and zolpidem on EEG beta frequencies are behavior-specific in rats. Neuropharmacology 47:163-174.

54. Bastien CH, LeBlanc M, Carrier J, Morin CM (2003) Sleep EEG power spectra, insomnia, and chronic use of benzodiazepines. Sleep 26:313-317.

55. Longmire AW, Seger DL (1993) Topics in clinical pharmacology: flumazenil, a benzodiazepine antagonist. Am J Med Sci 306:49-52.

56. Whitwam JG, Amrein R (1995) Pharmacology of flumazenil. Acta Anaesthesiol Scand Suppl 108:3-14.

57. Perrais D, Ropert N (1999) Effect of zolpidem on miniature IPSCs and occupancy of postsynaptic GABAA receptors in central synapses. J Neurosci 19:578-588.

58. Bacci A, Rudolph U, Huguenard JR, Prince DA (2003) Major differences in inhibitory synaptic transmission onto two neocortical interneuron subclasses. J Neurosci 23:9664-9674.

59. Woo J, Cho S, Lee CJ (2014) Isoliquiritigenin, a chalcone compound, enhances spontaneous inhibitory postsynaptic response. Exp Neurobiol 23:163-168.

60. Edwards FA, Konnerth A, Sakmann B (1990) Quantal analysis of inhibitory synaptic transmission in the dentate gyrus of rat hippocampal slices: a patch-clamp study. J Physiol 430:213-249.

61. Edwards FA (1995) Anatomy and electrophysiology of fast central synapses lead to a structural model for long-term potentiation. Physiol Rev 75:759-787.

62. Jonas P, Major G, Sakmann B (1993) Quantal components of unitary EPSCs at the mossy fibre synapse on CA3 pyramidal cells of rat hippocampus. J Physiol 472:615-663.

63. Nusser Z, Cull-Candy S, Farrant M (1997) Differences in synaptic $\mathrm{GABA}(\mathrm{A})$ receptor number underlie variation in $\mathrm{GABA}$ mini amplitude. Neuron 19:697-709.

64. Granger RE, Campbell EL, Johnston GA (2005) (+)- And (-)-borneol: efficacious positive modulators of GABA action at human recombinant alphalbeta2gamma2L GABA(A) receptors. Biochem Pharmacol 69:1101-1111.

65. Kessler A, Sahin-Nadeem H, Lummis SC, Weigel I, Pischetsrieder M, Buettner A, Villmann C (2014) GABA(A) receptor 
modulation by terpenoids from Sideritis extracts. Mol Nutr Food Res 58:851-862.

66. Cho S, Yoon M, Pae AN, Jin YH, Cho NC, Takata Y, Urade Y, Kim S, Kim JS, Yang H, Kim J, Kim J, Han JK, Shimizu M, Huang ZL (2014) Marine polyphenol phlorotannins promote non-rapid eye movement sleep in mice via the benzodiazepine site of the GABAA receptor. Psychopharmacology (Berl) 231:2825-2837.

67. Drexler B, Zinser S, Hentschke H, Antkowiak B (2010) Diazepam decreases action potential firing of neocortical neurons via two distinct mechanisms. Anesth Analg 111:1394-1399.

68. Griffin CE 3rd, Kaye AM, Bueno FR, Kaye AD (2013) Benzodiazepine pharmacology and central nervous systemmediated effects. Ochsner J 13:214-223.
69. Gao H, Smith BN (2010) Zolpidem modulation of phasic and tonic GABA currents in the rat dorsal motor nucleus of the vagus. Neuropharmacology 58:1220-1227.

70. Banaszak LJ (2000) Foundations of structural biology. Academic Press, San Diego.

71. Steriade M (2003) The corticothalamic system in sleep. Front Biosci 8:d878-d899.

72. Sejnowski TJ, Destexhe A (2000) Why do we sleep? Brain Res 886:208-223

73. Kopp C, Rudolph U, Löw K, Tobler I (2004) Modulation of rhythmic brain activity by diazepam: GABA(A) receptor subtype and state specificity. Proc Natl Acad Sci U S A 101:36743679. 